\title{
Cytogenotoxicity of Cymbopogon citratus (DC) Stapf (lemon grass) aqueous extracts in vegetal test systems
}

\author{
SAULO M. SOUSA, PÂMELA S. SILVA and LYDERSON F. VICCINI \\ Instituto de Ciências Biológicas, Departamento de Biologia, Laboratório de Genética \\ Universidade Federal de Juiz de Fora (UFJF), Campus Universitário, Bairro Martelos \\ 36036-900 Juiz de Fora, MG, Brasil \\ Manuscript received on October 24, 2008; accepted for publication on July 10, 2009
}

\begin{abstract}
The lemon grass, Cymbopogon citratus (DC) Stapf, is an important species of Poaceae family commonly used in the folk medicine in many countries. The aim of this study was to investigate the cytotoxic and genotoxic effects of aqueous extracts from C. citratus leaves on Lactuca sativa (lettuce) root tip meristem cells by cytogenetic studies that have never been done before for lemon grass extracts. For this, lettuce seeds were treated for $72 \mathrm{~h}$ with different concentrations of lemon grass aqueous extracts $(5 ; 10 ; 20$ and $30 \mathrm{mg} / \mathrm{mL})$. The percentage of germination, root development and cellular behavior were analyzed, and the results showed that the highest concentration of aqueous extracts reduced the mitotic index, the seed germination and the root development of lettuce. The extracts have also induced chromosome aberrations and cellular death in the roots cells of L. sativa.
\end{abstract}

Key words: aqueous extract, Cymbopogon citratus, cytotoxic effect, genotoxic effect, Lactuca sativa.

\section{INTRODUCTION}

The use of medicinal plants on phytotherapy is a result of empirical knowledge accumulated over the centuries about plant actions in several ethnic groups. Therefore, there are many questions about the standardization techniques for the production and exchange of phytotherapeutic agents (Negrelle and Gomes 2007).

The indiscriminate medicinal use of plants, usually toxic ones, may entail risks to health, because, similarly to the allopathic drugs, there is a threshold dosage for each phytotherapeutic agent. Thus, after an inadequate use, several disorders may occur, from intoxications to mutation events in somatic and germinative tissue, and it can lead to the development of somatic diseases, teratogenic effects and inherited genetic damages (Çelik and Aslantürk 2006, 2007, Pugliesi et al. 2007, Lubini

Correspondence to: Saulo Marçal de Sousa

E-mail: saulo_marcal@yahoo.com.br et al. 2008). Most carcinogens, for example, trigger their tumorigenic activity by the interaction of natural inductors of mutations with the DNA, leading to permanent genetic lesions, which are expressed as genetic mutations or chromosomal aberrations involving the cell cycle (Bronzetti et al. 1996, Gonzalgo and Jones 1997, Nunes and Carvalho 2003).

Among various species with medicinal properties, Cymbopogon citratus (DC.) Stapf (Poaceae), a species popularly known as "lemon grass", shows an infinite number of applications and is popularly used by people in many countries. In Brazil, for example, the tea, infusion and extracts of $C$. citratus, which are prepared with fresh or dry leaves, are often used in the popular medicine as a restorative, digestive, anti-tussis, effective drug against colds, with an analgesic, anti-hermetic, anticardiopatic, antithermic, anti-inflammatory of urinary ducts, diuretic, antispasmodic, diaphoretic and antial- 
lergic effect (Negrelle and Gomes 2007). Besides, the lemon grass extracts and their essential oils are also used in the food (flavoring), perfume and cosmetics industries, this use being of reasonable economical importance in various countries (Oliveira et al. 1997).

As a consequence of innumerous applications of C. citratus, several studies have been done aiming at enlarging the knowledge about the chemical composition of lemon grass leaves, which are the parts used for medicinal purposes. These studies have revealed that, although the chemical composition of the essential oil and aqueous extracts of $C$. citratus varies according to the geographical origin, the isolated and identified substances from the leaves are mainly alkaloids, saponin, âsitosterol, terpenes, alcohols, ketone, flavonoids, chlorogenic acid, caffeic acid, p-coumaric acid and sugars (Matouschek and Stahl 1991, Chisowa et al. 1998, Negrelle and Gomes 2007).

Although plant extracts of lemon grass have been extensively used in the folk medicine, scientific research has found some potentially toxic substance in this species. Hepatotoxic and nephrotoxic effects in mice treated with fluid extracts of C. citratus (30\% and $80 \%$ ) were observed (Guerra et al. 2000), indicating the necessity of more detailed research on its cytotoxicity (Negrelle and Gomes 2007).

Considering different techniques used to investigate toxicity, cytogenetic bioassay is an important tool to identify the effects of substances at the chromosome level and also on cell cycle (Campos et al. 2008, Dragoeva et al. 2008). Among the various available methodologies, tests that use plant roots are extremely useful in biological assays, relatively inexpensive and can easily be handled. In addition, plant cytotoxic bioassays have a good correlation with mammalian test systems (Fiskesjö 1985, Jovtchev et al. 2002, Yi and Meng 2003, Çelik and Aslantürk 2006, 2007, Lubini et al. 2008).

According to Campos et al. (2008), the great number of seeds, the great contact surface with the aqueous extracts, the high sensibility and the bigger chromosomes of $L$. sativa (lettuce) make this plant very useful for cytogenetic analysis.

Considering the potential therapeutic use of C. $\mathrm{Ci}$ tratus extract and the lack of data about its mutagenicity by cytogenetic bioassay, this paper described the effects of aqueous extracts of $C$. citratus leaves on seed germination, root growing, chromosome structure and cellular cycle of L. sativa.

\section{MATERIALS AND METHODS}

\section{Plant Material and Extracts Preparation}

Fresh leaves of $C$. citratus were collected at the Botanical Experimental Area of the Universidade Federal de Juiz de Fora (UFJF), and four aqueous extracts were prepared $(5 ; 10 ; 20$ and $30 \mathrm{mg}$, respectively, in $1 \mathrm{~mL}$ of distilled water). For the extraction of extracts, pieces of leaves were macerated in distilled water and after $24 \mathrm{~h}$, at room temperature; the extracts were filtered in filter paper before their application in the seeds bioassays. A voucher specimen was deposited at the CESJ Herbarium of the UFJF.

\section{GERMINATION AND RoOT GROWTH}

The different extracts concentrations and control were arranged in a completely random design with four repetitions (each repetition corresponding to 60 seeds of lettuce placed in a Petri dish). For control, lettuce seeds were germinated in distilled water. The germination percentage and root growth were evaluated after 12, 24, 36, 48, 60 and $72 \mathrm{~h}$ of exposure time.

\section{Cytogenetics Studies}

After $72 \mathrm{~h}, 10$ roots of control and different extracts concentrations were collected from each repetition (40 roots for treatment). These roots were fixed in cold methanol/ glacial acetic acid 3:1 (v/v) during 24h. Following this step, the roots were submitted to an enzymatic maceration (Pectinex NOVO NORDISK ${ }^{\mathrm{TM}}$ ) at $34^{\circ} \mathrm{C}$ for $1: 45 \mathrm{~h}$. Subsequently, the roots were hydrolyzed in $5 \mathrm{~N} \mathrm{HCl}$ for 11 minutes. The air dry technique (Carvalho and Saraiva 1993), five slides were prepared for repetition (20 slides for treatment, each one with 2 root-tips) and stained with Giemsa $10 \%$ for 3 minutes. The mitotic index was determined for each treatment and the presence of chromosomes abnormalities were also evaluated. Around 82,473 cells were counted for both evaluations. Each repetition corresponding to 60 seeds of lettuce was placed in a Petri dish. 


\section{STATISTICAL ANALYSES}

The percentage of germinated seeds, size of the roots, mitotic index and percentage of chromosome aberrations were obtained by the mean of each of the four repetitions of each treatment. The data were submitted to one-way analysis of variance (ANOVA) and comparison between the means of treatments with the means of control was performed using the Tukey test $(\mathrm{p}<0.05)$.

\section{RESULTS}

In this study, the mean percentage of germinated seeds decreased as the concentrations of lemon grass extracts increased, and the treatments $\mathrm{lem}_{2}(10 \mathrm{mg} / \mathrm{mL})$ at 24 , 36,48 and $60 \mathrm{~h}$, and $\mathrm{lem}_{3}(20 \mathrm{mg} / \mathrm{mL})$ and $\mathrm{lem}_{4}(30 \mathrm{mg} /$ $\mathrm{mL})$ at $36,48,60$ and $72 \mathrm{~h}$ showed significant difference from the control. The extract concentrations also showed a considerable influence in the time of seed germination. We observed that the seeds treated with higher concentrations of lemon grass $\left(\mathrm{lem}_{3}\right.$ and $\left.\mathrm{lem}_{4}\right)$ started the germination only after $36 \mathrm{~h}$ of exposure, and they exhibit lower index of germination when compared with the control, lem 1 and lem 2 (Table I).

In a general way, a similar behavior was observed on the root growth. $\mathrm{lem}_{3}$ and $\mathrm{lem}_{4}$ reduced significantly $(p<0.05)$ the root size when the average was compared with to control (Table II).

Regarding the cytotoxic evaluation, the higher concentrations of the extracts showed a cytotoxic effect on root cells of lettuce considering that mitotic index decreased significantly on $\mathrm{lem}_{2}, \mathrm{lem}_{3}$ and $\mathrm{lem}_{4}$ when the average of mitotic cells were compared to the control (Table II).

Together with the mitotic index, the cytological evaluation also revealed the occurrence of chromosome aberrations. It was observed a great percentage of lagging migration of the chromosomes, chromosome bridges, chromosome breaks, chromosome stickiness, polar deviation and micronucleus (Table IV, Fig. 1). Nevertheless, only at the highest concentration the percentage of all the chromosome aberrations were significantly different when compared to the control (Table IV, Fig. 1).

Additionally to these observations, on $\mathrm{lem}_{2}, \mathrm{lem}_{3}$ and $\mathrm{lem}_{4}$ treatments, cells with nuclear condensation,
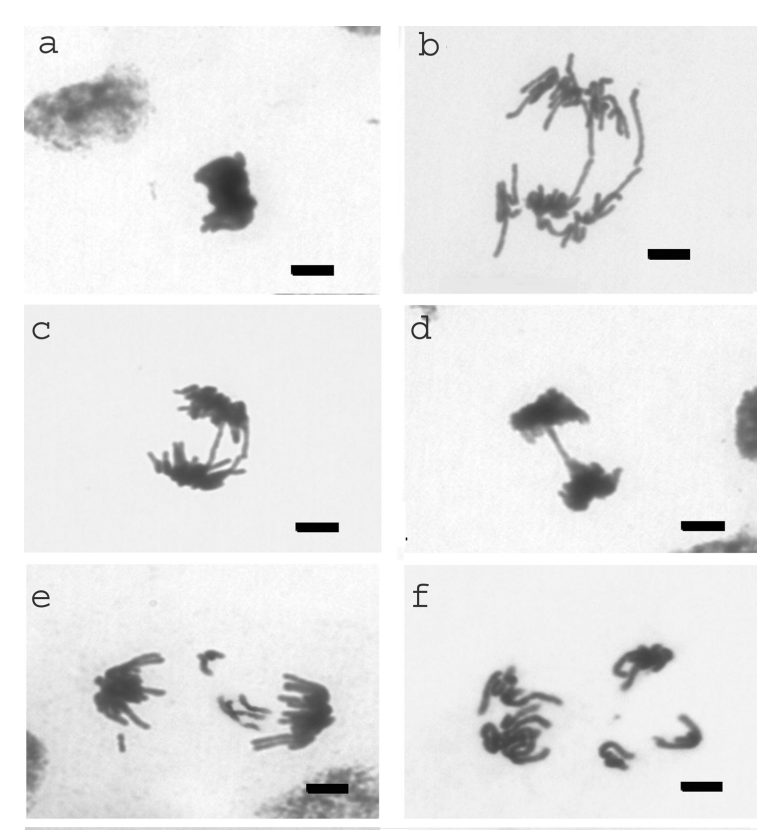

f
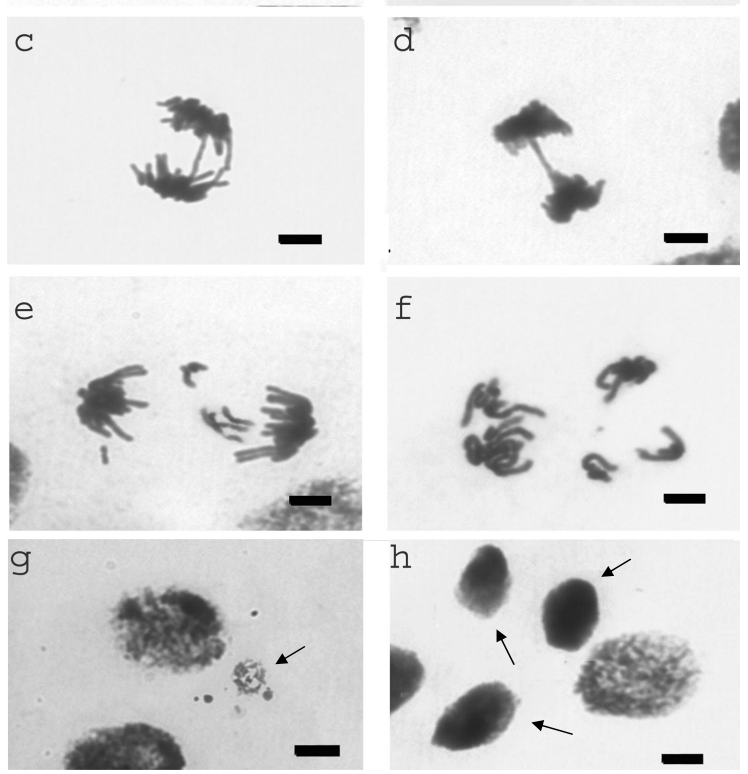

Fig. 1 - Chromosome aberrations observed in meristematic cells of lettuce exposed to aqueous extracts of lemon grass. Stickiness metaphase (a); Anaphase with chromosome lagging (b); Anaphases with bridges (c and d); Chromosomes breakage due to bridge termination (e); Polar deviation due to spindle alteration (f); Micronuclei formation (arrows) (g), Nuclear condensation due to cell death induction (arrows) (h). Bar $=5 \mu \mathrm{m}$.

apoptotic bodies and some nucleus with communications among them were observed. Again, $\mathrm{lem}_{2}, \mathrm{lem}_{3}$ and $\mathrm{lem}_{4}$ treatments showed significant differences $(\mathrm{P}<0.05)$ when compared to the control (Table V, Fig. 2).

\section{DISCUSSION}

Cytogenetic assays have been widely used in genotoxicity assessment to test compounds under both in vitro and in vivo conditions. Changes on the mitotic index, micronuclei formation and chromosome aberrations are important cytogenetic endpoints that are routinely used in citotoxicity and genotoxicity evaluation (SanSebastian et al. 1990, Krishna et al. 1991, Chacon et al. 2002, Ferreira et al. 2003, Zanoni et al. 2005, Pugliesi et al. 2007). 


\section{TABLE I}

Percentage mean of germination of lettuce seeds after 12, 24, 36, 48, 60 and $72 \mathrm{~h}$ of exposure to aqueous extracts of lemon grass.

\begin{tabular}{c|c|c|c|c|c|c}
\hline \multirow{2}{*}{ Treatments } & \multicolumn{5}{|c}{ Exposure $(\mathrm{h})$} \\
\cline { 2 - 7 } & 12 & 24 & 36 & 48 & 60 & 72 \\
\hline Control & - & $87.81( \pm 1.82)$ & $90.54( \pm 2.03)$ & $94.27( \pm 1.96)$ & $96.77( \pm 1.07)$ & $97.81( \pm 1.45)$ \\
\hline $1 \mathrm{em}$ & - & $75.93( \pm 3.12)$ & $83.96( \pm 3.88)$ & $87.40( \pm 2.65)$ & $91.56( \pm 1.80)$ & $94.90( \pm 2.64)$ \\
\hline $1 \mathrm{em}$ & - & $30.83( \pm 2.71)^{*}$ & $66.77( \pm 3.18)^{*}$ & $77.69( \pm 1.89)^{*}$ & $78.22( \pm 1.75)^{*}$ & $85.62( \pm 2.80)$ \\
\hline $\mathrm{lem}_{3}$ & - & - & $37.39( \pm 2.17)^{*}$ & $72.28( \pm 2.00)^{*}$ & $76.99( \pm 2.85)^{*}$ & $79.16( \pm 2.93)^{*}$ \\
\hline $\operatorname{lem}_{4}$ & - & - & $25.00( \pm 1.93)^{*}$ & $51.77( \pm 1.48)^{*}$ & $55.31( \pm 3.20)^{*}$ & $57.85( \pm 4.00)^{*}$ \\
\hline
\end{tabular}

$\mathrm{lem}_{1}$ : lemon grass aqueous extract $(5 \mathrm{mg} / \mathrm{mL}), \mathrm{lem}_{2}$ : lemon grass aqueous extract $(10 \mathrm{mg} / \mathrm{mL})$, lem 3 : lemon grass aqueous extract $(20 \mathrm{mg} / \mathrm{mL}), \mathrm{lem}_{4}$ : lemon grass aqueous extract $(30 \mathrm{mg} / \mathrm{mL})$. ${ }^{*}$ Significantly different from the control $(\mathrm{p}<0.05)($ Tukey test $)$.

TABLE II

Mean size (cm) of lettuce roots during $72 \mathrm{~h}$ of exposure in aqueous extracts of lemon grass.

\begin{tabular}{c|c|c|c|c|c|c}
\hline \multirow{2}{*}{ Treatments } & \multicolumn{7}{|c}{ Exposure (h) } \\
\cline { 2 - 7 } & 12 & 24 & 36 & 48 & 60 & 72 \\
\hline Control & - & $0.75( \pm 0.06)$ & $1.09( \pm 0.08)$ & $1.59( \pm 0.08)$ & $2.84( \pm 0.09)$ & $3.80( \pm 0.17)$ \\
\hline lem 1 & - & $0.70( \pm 0.04)$ & $1.11( \pm 0.05)$ & $1.62( \pm 0.01)$ & $2.89( \pm 0.03)$ & $3.45( \pm 0.17)$ \\
\hline $\mathrm{lem}_{2}$ & - & $0.72( \pm 0.02)$ & $0.82( \pm 0.04)^{*}$ & $1.45( \pm 0.05)$ & $2.19( \pm 0.16)$ & $3.55( \pm 0.29)$ \\
\hline $\operatorname{lem}_{3}$ & - & - & $0.27( \pm 0.03)^{*}$ & $0.70( \pm 0.02)^{*}$ & $1.28( \pm 0.03)^{*}$ & $1.52( \pm 0.07)^{*}$ \\
\hline lem $_{4}$ & - & - & $0.18( \pm 0.02)^{*}$ & $0.42( \pm 0.07)^{*}$ & $0.91( \pm 0.06)^{*}$ & $1.34( \pm 0.06)^{*}$ \\
\hline
\end{tabular}

$\mathrm{lem}_{1}$ : lemon grass aqueous extract $(5 \mathrm{mg} / \mathrm{mL}), \mathrm{lem}_{2}$ : lemon grass aqueous extract $(10 \mathrm{mg} / \mathrm{mL}), \mathrm{em}_{3}$ : lemon grass aqueous extract $(20 \mathrm{mg} / \mathrm{mL}), \mathrm{lem}_{4}$ : lemon grass aqueous extract $(30 \mathrm{mg} / \mathrm{mL})$. ${ }^{*}$ Significantly different from the control $(\mathrm{p}<0.05)$ (Tukey test).

\section{TABLE III}

Total of cells evaluated and mean of mitotic index from lettuce roots cells after $72 \mathrm{~h}$ of exposure to lemon grass aqueous extracts.

\begin{tabular}{c|c|c}
\hline Concentration & $\begin{array}{c}\text { Total of cells observed } \\
\text { for treatment }\end{array}$ & $\begin{array}{c}\text { Mean of Mitotic Index } \\
\text { for treatment }\end{array}$ \\
\hline Control & 20,324 & $6.89( \pm 0.71)$ \\
\hline$l e m_{1}$ & 18,432 & $6.63( \pm 0.08)$ \\
\hline 1 em & 15,668 & $2.42( \pm 0.49)^{*}$ \\
\hline lem $_{3}$ & 12,627 & $3.01( \pm 0.13)^{*}$ \\
\hline lem $_{4}$ & 15,422 & $2.43( \pm 0.37)^{*}$ \\
\hline
\end{tabular}

$\mathrm{lem}_{1}$ : lemon grass aqueous extract $(5 \mathrm{mg} / \mathrm{mL}), \mathrm{lem}_{2}$ : lemon grass aqueous extract $(10 \mathrm{mg} / \mathrm{mL})$, lem $_{3}$ : lemon grass aqueous extract $(20 \mathrm{mg} / \mathrm{mL}), \mathrm{lem}_{4}$ : lemon grass aqueous extract $(30 \mathrm{mg} / \mathrm{mL}) . *$ Significantly different from the control $(\mathrm{p}<0.05)$ (Tukey test).

In the present study, aqueous extracts of lemon grass leaves showed cytotoxic and genotoxic effect, which can be observed by a significant decrease of mitotic index and the great number of chromosome aberrations. The different kind and number of chromosome aberrations from lettuce seeds treated with the highest concentration $(30 \mathrm{mg} / \mathrm{mL})$ of the extracts indicate the mutagenic effect of lemon grass extracts. Apart from inducing mutations, natural plant products may modify the action of other substances on living organisms by transforming promutagens (chemicals that are not mutagenic themselves, but that can be biologically transformed into a mutagen) into mutagens (Sarkar et al. 1996). Because of this, the property of activating promutagens in plants that may enter the food chain or are used in phytotherapy is of great significance in view of the large number and types of chemicals produced by the plants. 
TABLE IV

Mean percentage of chromosomes aberrations in meristematic cells of lettuce after $72 \mathrm{~h}$ of exposure to lemon grass extracts.

\begin{tabular}{c|c|c|c|c|c|c}
\hline \multirow{2}{*}{ Concentration } & \multicolumn{5}{|c}{ Chromosome aberrations } \\
\cline { 2 - 7 } & $\mathrm{Lm}$ & Brks & Stk & Sa & $\mathrm{ABr}$ & Mcn \\
\hline Control & $0.13( \pm 0.01)$ & $0.60( \pm 0.09)$ & $3.89( \pm 0.54)$ & $0.16( \pm 0.05)$ & $0.42( \pm 0.07)$ & $0.23( \pm 0.07)$ \\
\hline lem & $0.17( \pm 0.01)$ & $0.63( \pm 0.15)$ & $4.17( \pm 0.62)$ & $0.30( \pm 0.12)$ & $0.58( \pm 0.09)$ & $0.28( \pm 0,04)$ \\
\hline $\mathrm{lem}_{2}$ & $0.14( \pm 0.01)$ & $0.61( \pm 0.14)$ & $6.20( \pm 0.31)^{*}$ & $0.22( \pm 0.04)$ & $11.72( \pm 0,91)^{*}$ & $0.27( \pm 0,04)$ \\
\hline $\mathrm{lem}_{3}$ & $15.31( \pm 2.02)^{*}$ & $0.66( \pm 0.08)$ & $9.00( \pm 1.39)^{*}$ & $0.24( \pm 0.09)$ & $23.68( \pm 2.28)^{*}$ & $0.30( \pm 0.06)$ \\
\hline lem $_{4}$ & $16.85( \pm 1.84)^{*}$ & $24.04( \pm 6.18)^{*}$ & $9.55( \pm 1.11)^{*}$ & $1.88( \pm 0.54)^{*}$ & $30.67( \pm 3.37)^{*}$ & $9.51( \pm 0,64)^{*}$ \\
\hline
\end{tabular}

lem $_{1}$ : lemon grass aqueous extract $(5 \mathrm{mg} / \mathrm{mL}), \mathrm{lem}_{2}$ : lemon grass aqueous extract $(10 \mathrm{mg} / \mathrm{mL}), \mathrm{lem}_{3}$ : lemon grass aqueous extract $(20 \mathrm{mg} / \mathrm{mL})$, lem 4 : lemon grass aqueous extract $(30 \mathrm{mg} / \mathrm{mL}) . \mathrm{Lm}=$ lagging migration; $\mathrm{Brks}=$ breaks; $\mathrm{Stk}=$ stickiness; $\mathrm{Sa}=$ spindle alterations; $\mathrm{ABr}=\mathrm{anaphases}$ with bridge; $\mathrm{Mcn}=$ micronuclei. *Significantly different from the control $(\mathrm{p}<0.05)$ (Tukey test).

TABLE V

Mean percentage of nuclear condensation, apoptotic bodies and nuclear communication in meristematic cells of lettuce after $72 \mathrm{~h}$ of exposure to lemon grass extracts.

\begin{tabular}{c|c|c|c}
\hline \multirow{2}{*}{ Concentration } & \multicolumn{3}{|c}{ Nuclear alterations } \\
\cline { 2 - 4 } & $(\%) \mathrm{Ncd}$ & $(\%) \mathrm{Ab}$ & $(\%) \mathrm{Ncm}$ \\
\hline Control & $4.80( \pm 0.61)$ & $0.16( \pm 0.03)$ & $0.31( \pm 0.15)$ \\
\hline $\mathrm{lem}_{1}$ & $5.42( \pm 1.37)$ & $0.18( \pm 0.03)$ & $0.30( \pm 0.10)$ \\
\hline $\mathrm{lem}_{2}$ & $12.74( \pm 1.24)^{*}$ & $0.18( \pm 0.03)$ & $0.31( \pm 0.60)$ \\
\hline $\mathrm{lem}_{3}$ & $27.40( \pm 3.62)^{*}$ & $4.37( \pm 0.48)^{*}$ & $0.34( \pm 0.08)$ \\
\hline $\mathrm{lem}_{4}$ & $37.22( \pm 4.49)^{*}$ & $7.97( \pm 0.85)^{*}$ & $5.65( \pm 0.84)^{*}$ \\
\hline
\end{tabular}

$\mathrm{lem}_{1}$ : lemon grass aqueous extract $(5 \mathrm{mg} / \mathrm{mL}), \mathrm{lem}_{2}$ : lemon grass aqueous extract $(10 \mathrm{mg} / \mathrm{mL})$, $l_{\mathrm{em}}$ : lemon grass aqueous extract $(20 \mathrm{mg} / \mathrm{mL}), \mathrm{lem}_{4}$ : lemon grass aqueous extract $(30 \mathrm{mg} / \mathrm{mL})$. $\mathrm{Ncd}=$ nuclear condensation; $\mathrm{Ab}=$ apopitotic bodies; $\mathrm{Ncm}=$ nuclear communications. *Significantly different from the control $(\mathrm{p}<0.05)$ (Tukey test).

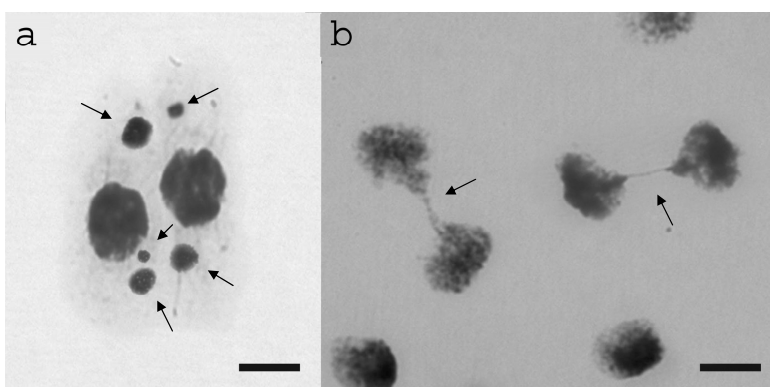

Fig. 2 - Nuclear modifications in roots cells of lettuce treated with aqueous extracts of lemon grass. Apoptotic bodies (arrows) and two condensed nucleus (a); Nuclear communications (arrows) (b). Bar $=5 \mu \mathrm{m}$.

Regarding different types of mutagenic alterations detected by cytogenetic techniques, micronuclei are thought to arise from both clastogenic (chromosome breakage) and aneugenic (chromosome lagging and ef- fects on spindle) effects, while chromosomes aberrations are thought to arise from chromosome breakage and exchange (Pugliesi et al. 2007). We observed all these effects in our study, mainly when $30 \mathrm{mg} / \mathrm{mL}$ were applied $\left(\mathrm{lem}_{4}\right)$. As we observed more prominent results with chromosome aberrations at the highest concentration, it is possible that the types of alterations are dose specific. For example, only lem 4 induced the formation of apoptotic bodies, chromosomes breakage, abnormal spindle behavior, micronuclei and nuclear communication. Thus, our results suggested caution with the use of lemon grass extracts, since some chromosome aberrations can be produced when elevated doses are ahandled.

The reduction of the mitotic index can be explained by the arrest of the division of the interphasic nucleus, as well as by death of interphasic nucleus, hindering the onset of the prophase and, thus, the division of the cells. 
In agreement with the second hypothesis, we observed various cells with cytoplasm shrinkage, nuclear condensation and apoptotic bodies, which are morphological aspects very common in the programmed cell death in plants (Solomon et al. 1999). These aspects were observed mainly in the lem 4 treatment, where the mitotic index showed a significant decrease in relation to the control. Similar results were observed in previous studies and cell death was the major depressor of the mitotic index (Çelik and Aslantürk 2006, 2007, Campos et al. 2008, Lubini et al. 2008).

In addition to the alterations discussed above, we also observed a great percentage of stickiness, mainly on metaphases observed at the highest concentration $\left(\mathrm{lem}_{3}\right.$ and $\mathrm{lem}_{4}$ ). This alteration in chromosome morphology reinforces the toxicity potentiality of some doses of $C$. citrates extracts, once these alteration evidences the toxic effect on the chromatin allowed by cell death (Campos et al. 2008, Lubini et al. 2008).

We also observed that the extracts affect root development and seed germination of lettuce. The reduction of the germination can be explained by the toxicity observed at the highest concentration of the lemon grass extracts. The decrease of mitotic index can also explain the reduction of root sizes at the highest concentration considering that the cell division is directly associated with root growth (Campos et al. 2008).

Valarini et al. (1996) also showed inhibitory effects of the essential oil suspension of $C$. citratus. The authors related total inhibition of seeds from Digitaria horizontalis, Sorghum halepense, Bidens pilosa, Euphorbia heterophylla and Raphanus raphanistrum. They suggested that lemon grass has a promissory application as a natural herbicide.

Finally, plant species represent a great source of biologically active compounds whose effects on heritable material are mostly unknown. The results obtained in the present study showed that, although $C$. citratus has a beneficial effect as a medicinal plant, serious problems and damages on cells by incorrectly usage, can be observed.

In order to reach more information and certain conclusions about this subject, further research should be performed with different test systems.

\section{ACKNOWLEDGMENTS}

The authors thank Conselho Nacional de Desenvolvimento Científico e Tecnológico (CNPq), Coordenação de Aperfeiçoamento de Pessoal de Nível Superior (CAPES) and Fundação de Amparo à Pesquisa do Estado de Minas Gerais (FAPEMIG) for the financial support.

\section{RESUMO}

O capim-limão, Cymbopogon citratus (DC) Stapf, é uma importante espécie da família Poaceae com uma comum utilização na medicina popular em vários países. O objetivo deste estudo foi investigar os efeitos citotóxicos e genotóxicos do extrato aquoso das folhas de C. citratus em células meristemáticas de Lactuca sativa (alface) por meio de estudos citogenéticos, uma vez que estudos desta natureza não existem para extratos aquosos de capim-limão. Para isso, sementes de alface foram tratadas por $72 \mathrm{~h}$ com diferentes concentrações de extratos aquosos feitos das folhas de capim-limão $(5,10,20$ e $30 \mathrm{mg} / \mathrm{mL}$ ). O percentual de germinação, desenvolvimento radicular e o comportamento celular foram avaliados e os resultados mostraram que as concentrações mais elevadas dos extratos aquosos reduziram o índice mitótico, o percentual de germinação das sementes e desenvolvimento radicular da alface. Os extratos também induziram aberrações cromossômicas e morte celular nas células das raízes de L. sativa.

Palavras-chave: extrato aquoso, Cymbopogon citratus, efeito citotóxico, efeito genotóxico, Lactuca sativa.

\section{REFERENCES}

Bronzetti G, Della-Croce C, Arentini P and FioRIO R. 1996. Antimutagenesis and anticancer effect. J Environ Pathol Toxicol Oncol 15: 59-64.

CAmpos JMS, DAVIDE LC, SoARES GLG AND ViCCINI LF. 2008. Mutagenic effects due allelopathic action of fern (Gleicheniaceae) extracts. Allelopath J 22: 143-152.

CARVAlHo CR AND SARAIVA LS. 1993. A new heterochromatin banding patterns revealed by modified HKG banding technique in maize chromosomes. Heredity 70: 515519.

ÇELIK TA AND ASLANTÜRK OS. 2006. Anti-mitotic and anti-genotoxic effects of Plantago lanceolata aqueous extracts on Allium cepa root tip meristem cells. Biologia 61: 693-697. 
ÇElik TA AND Aslantürk OS. 2007. Cytotoxic and genotoxic effects of Lavandula stoechas aqueous extracts. Biologia 62: 292-296.

Chacon DR, Dalla-Libera AN, Cintra DEC, CarVAlHo JCT, Oliveira GA AND Maistro EL. 2002. Absence of genotoxic and antigenotoxic effects of a standardized extract of the medicinal plant Solanum melongena on peripheral blood and bone marrow cells of Wistar rats. Cytologia 67: 417-422.

Chisowa EH, Hall DR AND FARMAN DI. 1998. Volatile constituents of the essential oil of Cymbopogon citratus Stapf grown in Zambia. Flavour Fragr J 13: 29-30.

Dragoeva AP, Nanova ZD AND KalcheVA VK. 2008. Allelopathic activity of micropropagated Origanum vulgare ssp. hirtum and its effect on mitotic activity. Allelopath J 22: 131-142.

Ferreira L, Carvalho JCT And Maistro EL. 2003. Standardized Solanum melongena extract presents protective effects against chromosomal aberrations induced by Doxorubicin in Wistar rat bone marrow cells. Cytologia 68: $177-181$.

FISKESJO G. 1985. The Allium test as a standard in environmental monitoring. Hereditas 102: 99-112.

Gonzalgo ML and Jones PA. 1997. Mutagenic and epigenetic effects of DNA methylation. Mutat Res 386: 107118.

Guerra mJM, Badell JB, Albajés ARR, Pérez HB, VALENCIA RM AND AZCUY AL. 2000. Toxicologic acute evaluation of the fluid extracts 30 and 80 porciento of Cymbopogon citratus (D.C.) Stapf (lemon grass). Rev Cub Plantas Med 5: 97-101.

Jovtchev G, Stergios M And Schubert I. 2002. A comparison of $N$-methyl- $N$-nitrosourea-induced chromatid aberrations and micronuclei in barley meristems using FISH techniques. Mutat Res 517: 47-51.

Krishna G, Kropko ML, Ciaravino V and Theiss JC. 1991. Simultaneous micronucleus and chromosomes aberration assessment in the rat. Mutat Res 264: 29-35.

Lubini G, Fachinetto JM, Laughinghouse HD, PARanhos JT, Silva ACF And TEdesco SB. 2008. Extracts affecting mitotic division in root-tip meristematic cells. Biologia 63: 647-651.

MatouscheK BK And Stahl BE. 1991. Phytochemical study of non volatile substance from Cymbopongon citratus (D.C) Stapf(Poaceae). Pharm Acta Helv 66: 242-245.
Negrelle RRB AND Gomes EC. 2007. Cymbopogon citratus (D.C) Stapf: chemical composition and biological activities. Rev Bras P1 Med 9: 80-92.

Nunes WB And Carvalho S. 2003. Avaliação dos efeitos clastogênicos do algodãozinho-do-campo-Cochlospermun regium (Mart ex Schrank) pilger, em células germinativas de Drosophila melanogaster. Genet Mol Biol 26: 545-549.

Oliveira ACX, Ribeiro PLF AND PAUMgartTem FJR. 1997. In vitro inhibition of CYP2B1 monooxygenase by âmyrcene and other monotherpenoide compounds. Toxicol Lett 92: 39-46.

Pugliesi GC, Andrade SF, Bastos JK and Maistro EL. 2007. In vivo clastogenicity assessment of the Austroplenckia populnea (Celastraceae) leaves extract using micronucleus and chromosomes aberration assay. Cytologia 72: 1-6.

SanSebastian JR, Lucenti SM, Mecca D, Giglio T, Madison N, Gongliewsin N, Messina D, CioTAlo VB And Matthews RJ. 1990. Micronucleus test (MNT) and chromosomes aberrations (CA) from a single animal. Environ Mol Mutagen 15: 52.

Sarkar D, Sharma A And Talukder G. 1996. Plant extracts as modulators of genotoxic effects. Bot Rev 62: $275-300$.

Solomon M, Belenghi B, Delledonne M, MenaCHEM E AND LEVINE A. 1999. The involvement of cysteine proteases and protease inhibitor genes in the regulation of programmed cell death in plants. Plant cell 11: 431-443.

VALARINi PJ, FRIGHetto RTS And SPADotTo CA. 1996. Potential of the medicinal herbage Cymbopogon citrates for the control of pathogens and weeds in irrigated bean crop. Cientifica 24: 199-214.

YI HL AND MENG ZQ. 2003. Genotoxicity of hydrated sulfur dioxide on root tips of Allium sativum and Viccia faba. Mutat Res 537: 109-114.

ZANONi FD, ANDRADE SF, BAstos JK And MAistro EL. 2005. Clastogenicity of the Austroplenckia populnea (Celastraceae) bark wood extract in Wistar rat bone marrow cells. Cytologia 70: 303-308. 